with legal garbage; ${ }^{11}$ and it confronts prison officials like Herman Spector with desparate problems of administration. Hopefully, the state will heed the advice of lawyers like Marshall Krause to end this cycle of frustration by finally creating a rational system of postappellate assistance.

11 Note, Burden of Federal Habeas Corpus Petitions from State Prisoners, 52 VA. I. REv. 486 (1966).

\title{
A Prisoner Looks at Writ-Writing
}

\section{Charles Larsen*}

I

WAS BORN IN CALIFORNIA forty-four years ago of Danisli parents who emigrated to the United States in the nineteenth century to escape the poverty of Europe. The poverty and strong old-country orientation of my youth fostered many conflicts with the revolutionary ideas of America as it plunged into the twentieth century. I allowed my resentments to play out in an antisocial manner. A long police record is all that $I$ gained from my behavior.

I was first committed to the custody of the California Department of Corrections in 1953 for second degree burglary. Paroled in 1957, I was returned to jail 75 days later for robbery and conspiracy to commit robbery. While imprisoned I studied law in the prison law hbrary and read every case and textbook I was able to lay my hands on. I used every conceivable remedy to attack my judgments of conviction and tried to redress other infringements of my rights which have occurred since being jailed. Although a number of publislied and unpublished decisions have been rendered by the courts in disposing of actions I filed, the important question-the validity of my imprisonment-has never been satisfactorily settled.

Why did I cease to hitigate my case? Justice, itself an elusive abstraction, is a fiction. It assumes an air of reality only because the inajority of people in this country he their lives without being required to seek justice. The unfortunate ones wlo seek justice find that it exists only in the minds of judges.

In prison I learned the printing trade and I was the editor of The Folsom Observer, a semiweekly newspaper published at Folsom Prison

* Charles Larsen, an inmate at San Quentin, was asked by prison officials to write this article for the California Law Review. His final manuscript was censored by the Department of Corrections and contains legal research and analysis for which Mr. Larsen assumes full responsibility. 
for the prisoners. While working at my prison print shop assignment I earned sufficient credits to graduate from high school. In my spare time I have been studying busmess administration through the facilities of the Extension Division of the University of California. My major field of interest is in accounting, management, finance, and taxes. I attended as a part-time student the classes conducted by the Prison College Project at San Quentin and taught by Dr. Stewart Adams, professor of criminology at the University of California at Berkeley.

During the years I have been in prison I have written a novel, six television plays, ten short stories, and a number of general feature articles. "A Candid Look at Prison Writ-Writers" is from The Aliens, a book I am presently writing about the way imprisonment alienates the prisoner from society.

\section{I}

\section{INTRODUCTION}

Among the prisoners serving time in California is a group whose pursuit of legal remedies to attack their convictions presents a unique social problem. These prisoners have been labeled with the uncomplimentary appellation, "writ-writers," by the prison officials and by their fellow prisoners. Actually, the term "writ-writer" is a misnomer because only a court or a judge may issue a writ. The name is one of convenience, but it behes the archaic conditions under which these prisoners must labor to produce the legal actions they file.

The state and federal courts, prison officials, and the prisoners themselves, while affected differently by the problem, are becoming increasingly concerned about the activities of writ-writers. The dockets of courts having jurisdiction over prisoners are being flooded by the rising tide of legal actions originating in the prisons. The prison officials are faced with new administrative problems in attempting to cope with and regulate the writ-writers. Finally, the prisoners' ineffectual attempts to act as their own counsel in challenging their convictions has them treading up the down legal escalator.

If the term "writ-writer" were to be defined in a dictionary of American-Enghish usage, the following definitions would possibly be included:

WRIT-WRITER (rĭt·rīt er) $\mathfrak{n}$. (1) an indigent person confined in a prison or jail under judgment of a court of law who prepares and files with a court those pleadings he believes will void such judgment. (2) a person who acts as his own lawyer while in prison. (3) Colloq. a person who repeatedly files frivolous legal actions in a court of law to harass his jailers. (4) a "jailhouse lawyer" is a writ-writer who does legal work for other prisoners for a fee. 
These four definitions encompass most of the prisoners litigating their cases in propria persona. Despite the fact that the majority of writ-writers possess intrinsic faith in the merits of their individual cases, they believe that prison officials have adopted the third definition. Prison authorities, they feel, have suspicioned writ-writing as a subterfuge through which inmates seek to shirk responsibility for the acts which brought them to prison, to escape punishment, and to rattle the cage in doing so. The breech between the two is exacerbated by the writ-writers' common belief that prison officials dehiberately coined the phrase "writ-writer" to degrade them. This attitude is at odds with the writ-writers' conception of themselves and causes ill feeling, hostility, and a breakdown of communication between them and prison officials.

Normally, a two-valued orientation exists within the prison; prisoners are either good or bad, good parole risks or bad parole risks, model prisoners or recalcitrants. However, because prison officials have adopted the third definition of writ-writers, this two-valued orientation breaks down in the case of prisoners who act as their own counsel. The writwriters feel that prison officials entertain a single value judgment about them: There are no good writ-writers or bad writ-writers; writ-writers are simply writ-writers.

II

\section{PRISONERS' MOTIVES IN WRITING WRITS}

Why do men in prison write writs if their objective is simply to "escape" from prison? One misconception should be clarified. The old saying that "typewriters have replaced the hacksaw" for breaking out of prison creates a prejudicial conception about writ-writers-more men still escape from prison than gain freedom through writs of habeas corpus! Litigating one's case is certainly much more time consuming than sawing out a heavy steel bar in a prison window and fleeing into the night.

Lawyers generally require at least a fifty dollar fee to travel to the prisons to consult with a prisoner. The ones not able to pay this sum must resort to the next best course of action-act as their own lawyers. The disadvantages to the prisoner are obvious. A lawyer, after examining the prisoner's transcripts or conducting an independent investigation of the facts, could immediately advise him on a course of action. Lacking the money to hire a lawyer, the prisoner must spend considerable time researching the law, preparing the required legal documents, and filing them. Sometimes years pass before the prisoner discovers what a lawyer could have told him in several weeks- that his case either has or lacks merit. The prisoners who have militantly prosecuted frivolous actions 
have wasted time they could have devoted to preparing theinselves for release from prison. The state, by shouldering these indigent prisoners with the responsibility of acting as their own counsel, has dissipated the taxpayers' money in wasted manpower and court costs.

If an analysis were to be made of the reasons prisoners elect to litigate their cases in pro per against seemingly insurmountable odds, the results would astound judges and lawyers. It is not the rash of decisions such as People v. Dorado, ${ }^{1}$ Escobedo v. Illinois, ${ }^{2}$ and Gideon v. Wainwright ${ }^{3}$ that send countless writ-writers to read barren case law in the prisons' scanty law hibraries and to hover for hours over their typewriters. Three important factors are contributing to the ever-increasing flood of legal actions emanating from the state prisons. They fall into the following loose categories: legal, psychological, and economic.

\section{A. Legal Factors}

A large percentage of writ-writers are not satisfied that they received due process of law when arrested, tried, and convicted. One common coinplaint is that they were represented by inadequate counsel. Many were impoverished, hiving at a bare subsistence level at the time of their arrest. Not having the money to employ private counsel, they were required to accept the services of a court-appointed public defender. Others, not represented by a public defender, employed inexpensive private counsel. Finally, some unsuccessfully defended themselves. In any of the above situations, the state is almost certain to obtain a conviction.

Because a large number of immates have been represented by a public defender, prisoners have a very low regard for this type of counsel. They beheve that the appointinent of a public defender is but token compliance with the constitutional right to counsel. The indigent defendant for whom the court appoints a public defender is convinced from the beginning he will not receive a fair and impartial trial. For example, a defendant having but several hundred dollars in the jail's booking office was arraigned in the San Francisco superior court on a robbery charge. When the court assigned the public defender to represent him, the defendant objected to the appointinent. He explained to the court that confined in jail awaiting trial on felony charges were approximately forty men who were also to be represented by the same public defender. It was impossible, he told the court, for one lawyer adequately to defend all forty defendants. The defendant, therefore, asked to be allowed to represent

162 Cal. 2d 338, 398 P.2d 361, 42 Cal. Rptr. 169, cert. denied, 381 U.S. 937 (1965).

2378 U.S. 478 (1964).

8372 U.S. 335 (1963). 
himself and petitioned the court for an order authorizing him to purchase and mamtain in the county jail a typewriter, law books, and the necessary supplies. The judge refused his request on the ground that the orderly functioning of the county jail could not be disturbed because one defendant wished to handle his own defense. The court then appointed the public defender to act in the capacity of "legal advisor" to the defendant.

After a trial the defendant was found guilty, and the court sentenced lim to the state prison. Nearly five years later this defendant refuses to believe that he was accorded his right to appear and defend in person as guaranteed by the California Constitution. ${ }^{4}$ Despite the record supporting his contention, state and federal courts have consistently refused to issue a writ of habeas corpus in his favor. Cases like this contribute to the unrest in the state prisons. One prisoner quite succinctly summed up his view of the problem by referring to the famed Washington lawyer, Edward Bennett Williams. "For a hundred grand," said the cynical writwriter, "Williams will guarantee that you don't go to the joint. If you're going to do wrong, make a bundle and buy justice like you would a hundred grand loaf of bread."

For every one that challenges the adequacy of the court-appointed counsel, there are ten or more writ-writers contesting the infringement of their constitutional and statutory rights. Prisoners today are more literate than their counterparts of twenty or thirty years ago. Today, prisoners have a keener awareness of their rights under the law, and any variance during the criminal proceedings with what they think to be their rights will impel them to seek relief in the courts. Possessing a better fundamental education, the prisoners have been able to penetrate the heretofore impregnable fabric of the law. They have mastered legal semantics and simplified it to their own needs. The law has become the panzer movement they use to strike out toward their elusive goals-to redress the deprivation of their rights.

It is not unusual, then, in a subculture created by the criminal law, wherein prisoners exist as creatures of the law, that they should use the law to try to reclaim their previously enjoyed status in society. The upheavals occurring in the American social structure are reflected within the prison environment. Prisoners, having real or imagined grievances, cannot demonstrate in protest against them. The right peaceably to assemble is denied to them. The only avenue open to prisoners is taking their case to court. Prison writ-writers would compare themselves to the dissenters outside prison, with one exception-their grievances are real or they imagine they are real. They are personally involved.

${ }^{4}$ CAL. Const. art. I, $\$ 13$ (West 1954). 


\section{B. Psychological Factors}

There are two obvious psychological motives for prosecuting legal actions from prison. The first is an outgrowth of the prison's social environment. Sentenced to serve a term in the state prison under what is termed the "Indeterminate Sentence Law," the prisoner is caught in a dilemma which causes him considerable frustration and despair. He does not know when his sentence will terminate, and must therefore choose between taking his case to court or waiting for the Adult Authority ${ }^{\mathfrak{}}$ to fix his term of imprisonment. If he chooses to write writs, it is only because the remote possibility of winning his case offers him better odds than waiting for the Adult Authority to set a definite sentence. On the other hand, he may fear that the authorities would disfavor anyone who denies his guilt by continuing to litigate his case. If the prisoner does not write writs, he may never get out; if he does write writs, he may never receive parole.

Many writ-writers have said that they would be able to make positive plans for the future if they knew when their sentences would end. They seem to feel that they are living in a vacuum where their fates are determined arbitrarily rather than by rule of law. One writ-writer very aptly summed up the majority's view with these words: "When I arrived at the prison and discovered that no one, including the prison officials, knew how long my sentence was, I had to resort to fighting my case to keep my sanity." This writ-writer, after twenty years in prison for the offense of robbery, still does not know how much time he will be required to serve. Psychologically, the writ-writer, in seeking rehef from the courts, is pursuing a course of action which relieves the tensions and anxieties created by the sentence system.

The second psychological type is the prisoner who writes writs to be "in." He is introduced to writ-writing by acquaintances who are writwriters. Men falling into this category are not the perennial writ-writers whose nanies continually appear on documents streaming into the courts. Usually, after a few unsuccessful forays into the legal realm, they stable their white chargers, hang their lances on the wall, and go about the business of serving their sentences.

\section{Economic Factors}

The last type of writ-writer to be discussed writes writs for economic gain. This group is comprised of a few unscrupulous manipulators who are interested only in acquiring from other prisoners money, cigarettes,

5 Cal. Pen. Code $\$ 3020$ (West 1956) expressly confers upon the Adult Authority the function of determining and redetermining the length of time a prisoner is to be confined in the state prison. 
or merchandise purchased in the inmate canteen. Once they have a "client's" interest aroused and determine his ability to pay, they must keep him on the "hook." This is commonly done by deliberately misstating the facts of his case so that it appears, at least on the surface, that the inmate is entitled to relief. The documents drafted for the client cast the writ-writer in the role of a sympathetic protagonist. After reading them, the inmate is elated that he has found someone able to present his case favorably. He is willing to pay to maintain the lie that has been created for hin. After years of futilely applying to the court for various writs, he will leave prison certain that he has not been accorded justice. On the other hand, when a prisoner turns his case over to a writ-writer he is left free to devote his time to serving his sentence. Prisoners who do this maintain an objective outlook. They do not become so emotionally involved with prosecuting their cases that they are unable to take advantage of the prison's self-betterment programs.

\section{III}

\section{COMMONLY SOUGHT LEGAI REMEDIES}

\section{A. The Writ of Habeas Corpus}

Of all the legal actions filed by prisoners, the most frequently souglit remedy is the writ of habeas corpus. Not all statutory remedies whicl the law provides for the "declaration, enforcement, or protection of a riglit, or the redress or prevention of a wrong"s are within the reacli of the writ-writer. Few writ-writers have the ability or the time to becone sophisticated enougl in law to successfully seek remedies other than the the writ of habeas corpus. It is evident, therefore, that there is a difference between the remedies theoretically available-those specifically provided for by law-and the remedies actually available to writ-writers. Possibly the courts of California were aware of this discrepancy when they expanded the scope of habeas corpus to include relief generally granted through mandamus, ${ }^{7}$ review, ${ }^{8}$ injunction,${ }^{9}$ and declaratory judgments. ${ }^{10}$

In California the writ of habeas corpus may be used not only to test the court's jurisdiction to render judgment of imprisonment; it can also be used to protect the fundanental rights of prisoners. ${ }^{11}$ It has been used to secure property wrongfully seized by custodial officers froin a prisoner's

\footnotetext{
${ }^{\circ}$ Cax. Crv. Pro. Code $\S 30$ (West 1954).

7 Id. $\$ \S 1084-97$.

8 Id. §§ 1067-77.

9 Id. $\S \S 525-26$.

$10 I d$. $\$ 1060$.

11 In re Riddle, 57 Cal. 2d 848, 372 P.2d 304, 22 Cal. Rptr. 472 (1962).
} 
cell, to review action taken by the California Adult Authority in granting or revoking prisoners' paroles, and to compel the transfer of a state prisoner to another jurisdiction in order that the petitioner could serve a sentence concurrent to his Cabifornia sentence. ${ }^{12}$ Infliction of cruel and unusual pumishments by custodial officers ${ }^{13}$ and interference with the right of access to the courts ${ }^{14}$ may also be remedied by the writ. In fact, many misfortunes that may befall an inmate confined in the state prison are actionable by habeas corpus, but the writ leaves much to be desired.

The major disadvantage of the writ of habeas corpus in California is that a superior court order denying the writ is not appealable. ${ }^{15} \mathrm{~A}$ writwriter can elect to file a petition for a writ of habeas corpus or for a writ of mandamus if an official refuses to perform a statutory duty which operates to the prisoner's detriment or injury. If he files an action for the writ of mandamus and it is denied, he has a right to appeal from the order. ${ }^{16} \mathrm{He}$ cannot appeal an order denying his application for the writ of habeas corpus. Therefore, he might never secure a hearing on his apphication for a writ of habeas corpus, but if he appeals an adverse order denying his application for a writ of mandamus his question will ultimately be resolved, either on appeal or upon remand to the court of original jurisdiction. The courts, then, in enlarging the scope of habeas corpus, have not resolved the legal dilemma facing writ-writers.

Further, if it has taken the prisoner a number of years to perfect his complaint, relief may be precluded because of the doctrine of laches. The state supreme court has held in a number of cases that a prisoner who fails to seek timely relief by habeas corpus is precluded from utilizing the writ. ${ }^{17}$ Of course, this position is debatable as the United States Supreme Court has held that the lapse of time does not cure constitutional violations. ${ }^{18}$ Nevertheless, the writ-writer must spend an additional year or so seeking relief in the federal courts under the Federal Habeas Corpus Act. ${ }^{19}$ All of this strips the writ of habeas corpus of its effectiveness. It is no longer the speedy and effective remedy the theorists hold it to be.

\footnotetext{
12 In re Portwood, 236 Cal. App. 2d 321, 45 Cal. Rptr. 862 (1965).

13 In re Jones, 57 Cal. 2d 860, 372 P.2d 310, 22 Cal. Rptr. 478 (1962).

14 In re Chessman, 44 Cal. 2d 1, 279 P.2d 24 (1955).

16 CAL. Pen. Code $\$ 1506$ (West 1956).

16 CAI. CTV. Pro. Code $\& 963$ (West 1954).

17 See, e.g., In re Schneider, 35 Cal. 2d 396, 217 P.2d 934 (1950); In re Swain, 34 Cal. 2d 300, 209 P.2d 793 (1949).

18 See, e.g., Fay v. Noia, 372 U.S. 391 (1963), in which the Court held that a prisoner who had failed to seek state relief in a timely fashion might nonetheless seek federal habeas
} corpus relief.

1928 U.S.C. $\$ \S 2241-55$ (Supp. II, 1966), amending 28 U.S.C. $\$ \S 2241-55$ (1948). 


\section{B. Complaints Filed Under the Civil Rights Act}

Disillusioned with the reluctance of the state courts to redress their grievances, writ-writers have increasingly turned to the federal courts for relief under the Federal Civil Rights Act. ${ }^{20}$ This has become the second most popular vehicle for airing their complaints. At least by filing a complaint in federal court, even if filed in forma pauperis, ${ }^{21}$ the writwriter is more likely to receive all his rights and privileges than in state courts. In the federal tribunal he is accorded the treatment that Congress has provided all citizens are to receive when seeking redress for an injury done to them "under color of state law." The fact that state officers are liable to an inmate under the Civil Rights Act for any wrongs done to him under color of state law has helped deter infringement by state officers of prisoners' federally protected rights.

IV

\section{COMIMON PROBLEMS CONFRONTING WRIT-WRITERS}

\section{A. The Subjective Point of View}

When a prisoner first attempts to utilize post-conviction remedies to attack his conviction, he views his case subjectively. In many instances, this prevents lim from bringing his case to a successful conclusion. The subjective viewpoint distorts the prisoner's conception of the pertinent facts; he is unable to identify the facts that are required to establisli a prima facie violation of his rights. With such a self-centered orientation, the prisoner invariably confuses his notion of the rights and limitations defined by constitutional law with those rights and limitations actually secured by the Constitution. The subjective inmate is the first to resentfully proclaim that his constitutional "rights" have been violated. If asked to relate the substance of the infringement, he will elaborate at great lengths on a number of grievances. However, a close scrutiny of the novice writ-writer's complaimts reveal that few of them come under the protection of either the state or federal constitution. Unable to distinguish between grievances and constitutionally protected rights, the prisoner is unable to make a showing which would warrant a court to intervene in the execution of his sentence. The tragedy is that many futile pleadings which wind up on court dockets have no merit. Over the years, if the writ-writer is persistent, he will acquire both an objective overview and a working knowledge of law and will eventually abandon his legalistic pursuits when he is able to measure the conduct of his trial against valid

2042 U.S.C. $\$ 1983$ (1964).

2128 U.S.C. $\$ 1915$ (1959). 
constitutional provisions. In the event a denial of due process has occurred during his trial, he is then better equipped to present the issues fairly.

\section{B. Inadequate Education}

Another major stumbling block encountered by many prisoners desiring to assault their convictions is the lack of adequate education. The uneducated writ-writer is not capable of intelligently analyzing the function of law in our society or of interpreting the court decisions construing the law. He commonly makes the mistake of selecting dictum from a decision and interpreting it as the absolute rule of the case. Many writwriters spend long hours in the prison law library hovering over the wellthumbed tomes. They may copy quite extensively from a number of decisions and emerge from the library clutching a handful of notes and citations which they beheve will support their allegations of denials of constitutional rights. Ask one at random: "What are the facts of People v. Doakes? Is there any similarity between the facts of your case and the Doakes case?" He will look at you with a puzzled expression and reply: "Hell, I don't know, but this is what the court said."

The second aspect of this problem is the novice writ-writer's inability to understand wliat is required to present a prima facie case entitling him to the relief lie seeks. Few prisoners realize that the burden of proof is on them, and the complexities of this requirement present a formidable precipice few writ-writers ever scale. It remains an insurmountable problem to the writ-writer until he has several years experience behind him. Many writ-writers turn to others for help, seeking, perhaps, another writ-writer's copy of a habeas corpus petition. If the copy received is itself faulty, the copier's petition will also lack the essentials to state a cause of action. Armed with this inadequate tool, the newly indoctrinated writ-writer, filled with enthusiasm at having been permitted a glimpse into the heretofore inaccessible legal realm, prepares his "writ" and files it. When notified by the clerk of the court that his petition has been denied, his belief in his case is reinforced. It is not long before he becomes convinced that a conspiracy is afoot to keep him in prison. A common reference aniong writ-writers is that "judges are all slopping out of the same trough." This attitude defeats the prisoner because as he doggedly pursues his writ-writing career, eacl writ that is denied reaffirms his belief that he was never destined to be afforded his constitutional rights-such "rights" become abstractions only the wealthy can afford. It is impossible to calculate the social harm generated by prisoners' lack of respect for the law stemming from being denied the assistance of counsel while litigating their cases in prison.

While some courts appear to recognize the problems writ-writers en- 
counter in doing their own legal work, none have yet made a definitive declaration regarding the assistance of counsel for prisoners seeking extraordinary writs. It was not until 1963 that the United States Supreme Court finally made definitive declaration of the right to counsel for criminal defendants on appeal. ${ }^{22}$ Having found, in that year, that indigent criminal defendants are entitled to counsel on appeal, the Court should now consider the rights of indigents to counsel in seeking postconviction rehef from prison.

Several years ago, a federal judge, in heu of appointing counsel to a habeas corpus petitioner, took a step which he thought would help writwriters. He rendered an opinion setting forth specifically, step-by-step, the requirenients that he expected of writ-writers in submitting petitions for the writ to his court. ${ }^{23}$ The decision was received with two reactions at the state prison at Folsom where the action originated. The petitioner in the case felt insulted that the court would be so presumptuous as to tell him how to write a "writ." The other writ-writers gleefully looked upon the opinion as an unprecedented windfall-here at last was the key to the front gate! Their revised petitions swelled the postal stream to the court only to be denied as rapidly as their preceding applications. Chaos reigned in the prison's legal world. Here was a federal judge who spelled out the requirements he expected in a petition for a writ of habeas corpus, yet not one of the subsequent petitioners was able to meet the court's criteria. That prison's legal-eagles ultimately looked upon the decision as a deliberate subterfuge to encourage the filing of worthless petitions.

\section{Inadequate Legal Source Materials}

The prison law hbraries are a constant source of discontent aniong writ-writers. Like newly landed immigrants who do not speak the language, they must use law hbraries to become conversant with law. Antiquated law books and insufficient time allocated for legal research ill prepares prisoners to handle their own cases. The ancient law books obstruct rather than assist them in their research. Without other legal reference sources, prisoners with no money must dig out decisions to use as citations. Unknown to them, niany of the citations they collect have been overruled or modified by later decisions.

In San Quentin prisoners are admitted to the law hbrary for a hmited period each week. However, legal volumes available in the library are severely limited. ${ }^{24} \mathrm{~A}$ writ-writer nuay spend as inuch as three months

22372 U.S. 353 (1963).

23 In re Mecks, 138 F. Supp. 327, 329 (N.D. Cal. 1956).

24 The San Quentin Prison Library is grossly inadequate for the comprehensive legal research needed to prepare legal actions adequately. For example, the California Appellate Reports and the California Supreme Court Reports terminate at 1955; California Juris- 
delving into the general issues of law he believes to be pertinent to his case. With meticulous care, lie will transcribe many of the decisions for use later in his cell. Certain that he has found a clearly defined rule of law which will sustain his position, he drafts his documents and submits them to a court liaving jurisdiction of the matter. If the action is one for the writ of habeas corpus, he will soon begin receiving summary denials until he has exhausted his state remedies. He then applies to the federal district court fully confident that that tribunal will not turn a deaf ear to his plea. Imagine his bewilderment when the United States District Court, in its opinion denying his application, cites recent California decisions which overrule or modify those lie found in the law hibrary. The federal court tells him that the state courts no longer adhere to the rule of law he "discovered" years before during his search of the antiquated law books. Frequently, this change in the law elininates the federal question necessary to convey jurisdiction upon the district court.

Under these circumstances constitutional and statutory remedies become meaningless. They do not exist for a prisoner if he cannot invoke the jurisdiction of a court authorized to grant relief. The indigent prisoner who must rely upon the privilege ${ }^{25}$ of using the prison's law library is effectively precluded from exercising and enjoying the remedies provided by law. Whether or not this presents an infringement of the prisoner's right to due process of law is a question yet to be decided by the courts.

\section{Prisoners' Attempts to Defeat the System}

Because of the impediments outhined above, few writ-writers are able to communicate effectively their grievances by making out a prima facie case. To do this it is necessary to allege ultimate facts; and, it is preferable, though not necessary, to cite authorities supporting their contentions. Since the prison law library is not a very fertile source of relevant citations, writ-writers have for many years purchased individual printed decisions from the West Publishing Company. For a nominal fee that company makes available any printed decision it has in stock. Because prison restrictions on some types of legal pubhications have recently been relaxed, prisoners with funds can now subscribe to several legal periodicals: the Sacramento Legal Press and the Advanced California Reports. Writ-writers coming into possession of these publications are able to keep their fingers on the pulse of the law. Quite a number of them

prudence, McKinney's California Digest, and Corpus Juris have not been replaced by their respective second series; Shepards Citations terminate at 1954; and there are no United States Supreme Court Reports.

25 "[T] drawn upon misuse. . . . Personally owned law books are not permitted." Cal. Dep't of Corrections Rules, ch. II, art. 6, Rule D-2601 (1967). 
zealously read them awaiting an opinion they can use. Another source yielding good dividends is the daily newspapers. When a news item appears about an important decision contaming a hint of its applicability, writ-writers dash off letters seeking complimentary copies of it from the clerk of the court.

Legal documents filed by an attorney representing an imprisoned chent usually provide a bonanza of legal nuggets. Fortunate is the writwriter who discovers another prisoner with a similar case who is represented by counsel. He simply presents his case the way the lawyer has done it for the other prisoner. Yet, the sources of law available to the writ-writer do not actually help him prepare his case. Absent are current texts on pleading and procedure. McKinney's Digest (1st series) and California Jurisprudence (1st series), while on the shelves of the law library at San Quentin, are shunned by most writ-writers. They have been "burned" too often in using authorities cited in these volumes, because many cases in both sets have been modified or overruled by subsequent decisions.

When decisions do not lielp a writ-writer, he may employ a handful of tricks which damage his image in the state courts. Some of the not too subtle subterfuges used by a small minority of writ-writers would tax the credulity of any lawyer. One writ-writer simply made up his own legal citations when he ran short of actual ones. In one action agamst the California Adult Authority imvolving the application of administrative law, one writ-writer used the following citations: Aesop v. Fables, First Baptist Church v. Sally Stanford, Doda v. One Forty-four Inch Chest, and Dogood v. The Planet Earth. The references to the volumes and page numbers of the nonexistent publications were equally fantastic, sucli as 901 Penal Review, page 17,240. To accompany each case, he composed an eloquent decision which, if good law, would make selected acts of the Adult Authority unconstitutional. In time the "decisions" freely circulated aunong other writ-writers, and several gullible ones began citing them also.

Sometimes the knavery employed by writ-writers becomes an administrative problem which must be unraveled by the prison officials. Once a prisoner is paroled, he acts under the threat of being returned to prison for violating the conditions of his parole. When a parolee is returned to prison by the Division of Adult Paroles, he is entitled to a learing before the Adult Authority which has the power either to revoke the parole or to reinstate it. During the hearing the parolee is demed counsel and the riglit to present witnesses and evidence in his behalf. The revocation procedure presents a sore spot to most of the hundreds of parolees returned to prison each year. They like to behieve that the constitutional 
guarantee to counsel and the right to present evidence in their behalf applies during this administrative hearing. One writ-writer composed a fictitious decision which held that a parolee is entitled to counsel when appearing before the Adult Authority on charges of violating his parole. The decision declared that failure to observe this requirement amounted to a denial of due process of law which invalidated the action taken by the Adult Authority. The "decision" ran like spilled mercury around the prison yard. Prisoners swamped the prison officials with hopeful inquiries regarding when the Adult Authority was going to reschedule their cases for hearing in hight of the "decision." The associate warden of the prison finally had to address the prisoners over the prison radio. $\mathrm{He}$ explained that the state's attorney general had conducted an investigation and found no evidence of such a case being decided by the courts. Of course, the prisoners refused to accept this bit of adverse news. It was nearly six inonths before the furor died down.

\section{$\mathrm{v}$}

\section{WRIT-WRITERS ASSISTANCE TO EACH OTHER}

Rule D-2602 of the Rules of the Cahifornia Director of Corrections expressly forbids a prisoner to assist or receive assistance from another in the preparation of legal documents. ${ }^{26}$ It violates the rule even to type legal documents for a fellow inmate. Violations of this rule are not as prevalent as one might suppose. Lacking a legal education, a writ-writer must devote a large portion of his time plunging aimlessly through a jungle of constitutional law, criminal law and procedure, extraordinary remedies, and countless other details before he is able intelligently to prepare and present his case to the courts. The average writ-writer is left with little free time and is therefore unable to assist others.

The indigent prisoner inust utilize the facilities of the prison's law library. He cannot check out any of the books. ${ }^{27}$ The cases he selects to cite must first be land copied from the reports. If he has a typewriter, he will transcribe them into typewritten copies for later reference. However, these copies, as well as copies of previously filed legal actions, pass freely from hand to hand in violation of prison rules. Most assistance, lowever, is verbal in the form of advising another writ-writer where to look for particular citations and what type and form of legal action to

26 "Do not assist or receive assistance from another in the preparation of legal docum ments. Any brief or petition not pertaining to your own case found in your possession will be confiscated." Id., Rule D-2602.

27 "There will be a suitable place in each institution where inmates, with the permission of the designated employee, may have access to study such institution law books as are available to them." Id. (Statement of Purpose). 
file, suggesting techniques for pleading an issue, and outlining the procedure the inquirer will encounter:

The prison officials use Rule D-2602 28 to curb the activities of the "jailhouse" lawyers who were discussed earlier, but injustices occur in the application of the rule. Prisoners wlio have borrowed legal material from other prisoners are the ones most likely to be punished. Indigent prisoners are unable to purchase much of the legal material they need, and so they borrow it from others. If custodial officers find this borrowed material in a prisoner's cell during either a routine search or a "shakedown," the prisoner is subjected to a hearing before the disciplinary committee. Unfortunately, this rule is applied indiscriminately to the indigent writ-writer as well as to the "jailhouse" lawyer. Months, even years of research have been confiscated by the prison's disciplinary committee because it was in the possession of an inmate not its compiler. Though the courts are generally sympathetic in such cases, they are usually powerless to assist the prisoner because the complaining writwriter is not able to establish a case against the custodial officers. In recent years, however, prison officials have not been as strict in enforcing this rule against indigent writ-writers as they were in the past. The rule is still on the books, however, and can be invoked at will by the custodial force.

One type of legal assistance not prohibited by Rule D-2602 is the filing of a legal action by one writ-writer which may be beneficial, or even detrimental, to the entire prison population if it is brought to a successful conclusion. One veteran writ-writer, referred to by the other prisoners as the "Jamaica Judge," finally tired of being denied parole consideration at his annual appearances before the Adult Authority. He decided to do something about it, and during the course of his legal research he noticed that Article X of the California Constitution of 1872 expressly provided that the Board of Prison Directors was to receive no salary for its services. ${ }^{29} \mathrm{He}$ also found that in 1944 the state legislature created the California Department of Corrections and the California Adult Authority. Originally, one of the duties of the Board of Prison Directors was to fix prison terms and to grant paroles. By subsequent legislation, this function was transferred to the Adult Authority, and the state legislature enacted a provision providing that members of the Adult Authority were to receive salaries. The "Jamaica Judge" reasoned that the statute authorizing salaries for members of the Adult Authority was in violation of Article $\mathrm{X}$ of the Cahfornia Constitution. He filed a coinplaint in the district court seeking an injunction to restrain the state

28 Id.

28 CarIf. Const. art. X, $\S 4$ (West 1954). 
treasurer from paying salaries to members of the Adult Authority. The complaint was dismissed by the district court and the case went to the United States Court of Appeals. While pending there, the case caused an unexpected reaction. Officials of the state caused a proposition to be added to the state ballot to remove what was termed "obsolete constitutional provisions." Among the "obsolete" constitutional provisions was the one upon which the "Judge's" case was predicated. During the general election in November of that year, the voters approved the proposition ${ }^{30}$ and the question raised by the "Judge" was dismissed as moot.

Whether a successful outcome to the suit would have been beneficial to the other prisoners will never be known. But the "Judge" had a lot of fans rooting for him inside the prison. Other prisoners, too, had felt the sharp sting of the Adult Authority's action in their cases. Rather than presenting a serious problem the "Judge's" suit was a healthful psychological outlet for the prisoners.

VI

THE PRISONER'S VIEW OF THE CALIFORNIA LEGAL SYSTEM

Statistical tables have been appended to several decisions rendered by the United States Supreme Court and the California courts which purport to show the insurmountable odds agamst a state prisoner "winning" his case. These tables support prisoners' feelings that justice in California is administered capriciously, and that the court system is able to, and frequently does, use the "Taw" to rationalize decisions reached on other grounds. Prisoners are convinced that courts frequently treat similarly situated individuals differently according to their whims.

\section{A. The Two-Valued Aspect of the Law}

Two hypothetical cases will best illustrate the poimt. In both cases police officers, without a warrant, searched two suspects' houses after arresting them on a public thoroughfare one block from their residences. At the time of the arrests the officers found no evidence that a crime had been committed. The officers then conveyed the suspects to their homes which they searched without a warrant. In both residences the officers found a quantity of herom. The evidence so seized was admitted into evidence during the trial over the defendants' objections and a verdict of guilty was found in both cases. One case becomes meritorious on appeal if the rule originating in Agnello v. United States, ${ }^{31}$ a United States Supreme Court decision, is applied. However, the other case lacks

30 Cartr. Const. art. X, \& 4, repealed Nov. 8, 1960 (West Supp. 1967).

31269 U.S. 20 (1925). 
merit if the court applies the rule followed in People v. Acosta. ${ }^{82}$ The Acosta rule permits in California what the Agnello rule prohibits. In one of the two hypothetical cases the judgment is reversed while in the other the judgment is affirmed.

This two-valued concept of law is not unique to appeals; it is also found in cases wherein prisoners seek to utilize extraordinary remedies to attack their judgments of conviction. The wide latitude exercised by the courts in disposing of these types of actions tends to destroy prisoners' faith in the law. Some cases remain frivolous while others suddenly bloom ineritoriously because of this two-valued application of the law. Some scholarly writ-writers contend there is a lack of uniformity among the decisions rendered by the courts of California. One gnarled writ-writer, confined in the state prison at Folsom, declared that should the state appellate courts desire to affirm a judgment of conviction, they could choose a dozen law reports at random from the shelves and select therefrom a number of decisions which would support their reasoning. On the other hand, he said, the same court could hift a different dozen books from the shelves and choose any number of decisions upon which they could base an opinion reversing the judgment of conviction. This example may be an oversimplification of the problems involved in deciding a case; yet when a situation exists where the state courts can legally deny relief to one person while granting it to another, upon the same set of facts, prisoners develop a cynical attitude toward the law.

Actually, writ-writers do not "win" their cases; they simply secure those rights they should have enjoyed froin the beginning. In most cases, if the trial courts had been alert to protect many of the defendants' constitutional rights, the odds are that quite a few of them would not have been convicted. So, it is quite a hollow victory when a penniless prisoner, after years of struggling, finally vindicates his riglits.

\section{B. Prisoners' Cynical Attitude Toward The Law}

The consensus among writ-writers imprisoned in California prisons is that they live in the most legally impoverished state in the Union. This opinion is based upon their comparisons of opinions rendered by California courts and those of other jurisdictions. The legal profession holds the opposite view. In a recent article in the Sacramento Legal Press writwriters had the occasion to read the following: "The legal community justly considers the California Supreme Court one of the most progressive among state courts. Its well reasoned opinions have earned the court nationwide respect." ${ }^{33}$ These words caused the writ-writers who read

82213 Cal. App. 2d 706, 29 Cal. Rptr. 241 (1963).

83 Sacramento Legal Press, Dec. 21, 1967, at 1, col. 1. 
them to snort with disgust. One prisoner who has been fighting his case for several years had this to say in reply to the article: "Theoretically, the opinions of the California Supreme Court leave little to be desired. But, in the field of applied law the opinions mean nothing because of that court's discrimination in applying the law."

Candid writ-writers themselves best express what a majority of California prisoners feel about the highest tribunal of the state. A lawyer serving a life sentence for murder said: "I practiced law outside for over thirty years. During that time my position as a lawyer commanded the respect of the courts. Now that I am prosecuting my own case from inside the prison $I$ find that I'm just another writ-writer. This fact is reflected by the disregard the courts have for my contentions. In fact," he concluded, "years ago a client of mine had the same issues I'm using in my case. I had no trouble securing a reversal for him." Another writwriter had this to say: "The courts seem to have adopted the attitude that we don't need our constitutional rights as long as we have the Department of Corrections. The courts entertain some dubious concept that imprisonment will cure all our constitutional ills. Look at the summary manner in which the courts dispose of actions originating from the prison. With their summary denials," he said, "the courts seem to be saying that we in prison are presumptuous to think we are entitled to the protections afforded by the constitution."

The prisoners find no Learned Hands, no Thurgood Marshalls, no Earl Warrens, nor Arthur Goldbergs on the California bench. They even scoff at the Dorado decision as being no more than a rule of law that should have been in effect when the state constitution was adopted.

\section{Actual Causes of the Low Percentage of "Wins"}

Prisoners fail to succeed in more of their legal actions because the courts of California have been reluctant to make a definitive declaration of prisoners' rights under the law to litigate their cases. The courts presume prisoners are sufficiently sophisticated to be able to draft a "statement of facts" which establishes an infringement of their rights. This is a fallacy which works to the detriment of the prisoner. If the majority of the prisoners do not comprehend what their constitutional rights are and what acts constitute an infringement thereof, how can they present their complaints to a court in a manner which will withstand attack by the attorney for the state? They will not be able to as long as the courts refuse inquiry into the ability of the state prisoners to present effectively a factual statement which will establish a violation of their rights.

There are but a handful or writ-writers in the state prisons who are 
capable of drafting the pleadings necessary to invoke the jurisdiction of the courts to entertain remedies other than habeas corpus. Those that cannot do this must resort to the writ of habeas corpus. That writ, being a discretionary one, need not issue despite allegations contained in the pleadings entitling one to an injunction. There are no habeas corpus decisions in the California reports granting injunctive relief. The California courts, in enlarging the scope of habeas corpus, have abridged the writwriter's right to seek relief through other writs or courses of action. If a prisoner is forced to seek habeas corpus, lie cannot appeal an adverse order denying the petition, which he could do by filing a different type of civil action for the protection of the same right. Actually, if the climate of the law permitted writ-writers to pursue the remedies provided by the Code of Civil Procedure to protect their rights and to redress or prevent wrongs threatened them while in prison, their chance of bringing their cases to a successful conclusion would be greatly enhanced.

VII

PROPOSED SOLUTIONS TO INDIGENT PRISONERS' LEGAL PROBLEMS

The above presents from the writ-writer's point of view, a side of prison life that heretofore has never been viewed outside the walls. One thing is apparent: The person convicted of a crime and sentenced to prison sees a flagrant disregard of the meaning and spirit of justice in this country. Who is responsible for this attitude in an environment where penniless prisoners are looked upon with contempt when they seek relief in pro per and forma pauperis in the state courts? Is it that the prisoners' concept of the law and its meaning to them has disintegrated because of the way they have seen justice administered? Or is it simply that they are frustrated by the obstacles they encounter while in prison fighting their cases?

Apologists contend that imprisonment necessarily entails denying the prisoner many of his constitutional riglits. Cases hold that the orderly administration of the prison requires it. ${ }^{34}$ Prison administrators first foisted this concept upon courts, and the courts, by written decision, have promulgated this American ideal. Under its umbrella a citizen's constitutional riglits are stripped aside because of imprisonment resulting from conviction in a criminal prosecution. In effect, this is an additional punishment not prescribed by the legislature for the offense for whicl the citizen is imprisoned.

The legislature alone is empowered to define a crime and to fix the

\footnotetext{
34 Ortega v. Ragen, 216 F.2d 561 (7th Cir. 1954); United States v. Ragen, 213 F.2d 294 (7th Cir. 1954); Adams v. Ellis, 197 F.2d 483 (5th Cir. 1952); Siegal v, Ragen, 180 F.2d 785 (7th Cir. 1950).
} 
punishment therefor. ${ }^{85}$ Courts in other jurisdictions have declared that a judgment which provides or allows, during its execution, a penalty not prescribed by law, is void in so far as the increased punishment is concerned. ${ }^{36}$ Any statute which authorized stripping aside a portion of a person's constitutional rights by those charged with the execution of a criminal judgment as part of the punishment to be inflicted would be declared unconstitutional. Yet, in Cahifornia the executive branch of the government, in the administration of its prisons does just this; the impoverished prisoners, not able to hire a lawyer, are unable to avail themselves of the remedies provided by law for the "declaration, enforcement, or protection of a right, or the redress or prevention of a wrong." This amounts to a denial of the equal protection of the laws, and is being perpetuated by the reluctance of the state courts to take a firm stand to protect the fundamental rights of prisoners to avail themselves of the postconviction remedies.

The courts of Cahifornia must zealously protect the rights of the disenfranchised prison minority. Enlarging the scope of the writ of habeas corpus has not proved satisfactory. The courts of this state have consistently held that a person's imprisonment becomes illegal when, though at first lawfully confined, he is deprived of some right to which he is lawfully entitled. If a prisoner can establish these facts to a court's satisfaction, he is entitled to the writ of habeas corpus only to remedy the situation, not to redress him for any wrong suffered by the deprivation of the right complained of.

Once convicted and sentenced to prison, the individual becomes a ward of the state; his very existence, his life, his safety and well being depend upon the abihty of the executive department to exercise properly the functions and duties it has pertaining to the prison. Unfortunately, the writ-writer and the prison official do not agree on the proper exercise of the functions and duties of a prison official regarding the prisoner litigating his case while in prison.

Several years ago a similar disagreement existed between the writwriters and the courts of California. At one time, indigent defendants appealing their judgments of conviction had to prepare and file their own briefs. To do so they were forced to go through much of the same routine that writ-writers are now experiencing. Repeatedly, the indigent appellants requested the reviewing courts to appoint counsel to represent them on appeal. The courts invariably refused to do so. The only appellants fortunate enough to have counsel to perfect their appeals were prisoners under sentence of death. The prison officials were "stuck" with

35 See, e.g., In re Ellsworth, 165 Cal. 677, 133 P. 272 (1913).

88 State v. Swanson, 70 S.D. 313, 17 N.W.2d 303 (1945). 
these lawyerless appellants in much the same way as they are stuck with today's writ-writer. In refusing to appoint counsel to represent such appellants, the state courts steadfastly refused to declare that due process of law required the appointment of counsel. No guidelines were formulated by the courts for the prison officials to follow. It was not until one prisoner, dissatisfied at not having counsel appointed to perfect his appeal, challenged the state procedure in the United States Supreme Court. In Douglas v. California, ${ }^{37}$ that Court declared that due process of law required that indigent defendants appealing their cases have counsel appointed to represent them. Until that decision, appellants in the state prisons struggled against overwhelming odds in the prisons' legal underground to compile inadequate briefs for submission to appellate courts. How many invalid judgments of conviction will stand because of the ill-prepared efforts of such appellants?

The indigent writ-writer in prison today stands exactly where the poor appellant did four years ago. The prisoner who has money can engage the services of a lawyer to make a direct or collateral attack upon his judgment of conviction. He is not necessarily restricted to use the writ of habeas corpus; he does not liave to overcome the obstacles within the prison that confront poor writ-writers. And most important, the monied prisoner, when lie hires a lawyer, frees himself from the time-consuming task of preparing his own pleadings; he is left free to take advantage of the prisons' programs of self-improvement. Additionally, the penniless writ-writer is open to reprisal from the state officers charged with executing his sentence if they happen to be named in a legal action he files.

The writ-writer is caught in a dilemma which up to now has had no solution. What is needed is a decision like Douglas v. California in order that the postconviction remedies provided by law may become realities. This can only be accomphished by providing counsel to poor prisoners who have cases which warrant intervention by the courts to protect their rights. The state legislature has enacted a law which provides that the Department of Corrections is to pay for lawyers appointed to represent prisoners charged with a crime committed while serving their sentences. Cannot the state recognize that the deprivation of a person's constitutional rights during the course of a criminal prosecution or during a prisoner's confinement presents just as serious a social harm as does a crime, and that some tangible unethod must be provided to enable prisoners to challenge effectively such infringements?

The State of Illinois solved many of the problems which now exist in the prisons of California when it enacted the "Post-Conviction Remedy

37 Douglas v. California, 372 U.S. 353 (1963). 
Act. ${ }^{338}$ The act provides for lawyers to litigate prisoners' cases in instances where their causes are meritorious and the prisoner is entitled to relief. An agency could be established by the California legislature, comprised of lawyers, completely separate from the Department of Corrections, to examine prisoners' grievances. If, after investigating the facts, the lawyers believed that a prisoner has, in fact, been deprived of some right, they could commence the appropriate legal action to rectify the situation.

\section{CONCLUSION}

Because of their imprisonment writ-writers cannot make any significan contribution toward resolving the problems of acting as their own counsel in prison. On the one hand, prison officials possess the power to trample underfoot what remaining constitutional rights writ-writers possess in litigating their cases in pro per. And, at the other extreme, the courts have displayed a devil-may-care attitude about whether or not the writ-writers are able to present statements of fact which would entitle them to relief. The courts seem to have been content to rule on issues inadequately presented to them by the writ-writers, rather than on what a lawyer could present on behalf of those indigent writ-writers. Only an enlightened, progressive society, having the courage to fashion elusive legal abstractions into effective instruments of law, can place writ-writers on an equal footing with those having funds to employ private counsel. Until this is done, the remedies provided by law to protect prisoners' rights and to redress or prevent wrongs threatened them while in prison will remain meaningless and unattainable to the writ-writers. Is there equal justice under the law? Just ask any one of nearly forty writ-writers waiting for hours in near-freezing weather outside a small booth on the prison's main yard to have their legal documents notarized. Any one of them will answer this question.

38 Irc. Stat. AnN. Ch. 38, § 1222-24 (1963). 